\title{
Communication \\ Reusing Grey Water to Lower Temperatures in the Mediterranean Basin Cities
}

\author{
Giuseppe Maggiotto
}

check for

updates

Citation: Maggiotto, G. Reusing Grey Water to Lower Temperatures in the Mediterranean Basin Cities. Earth 2022, 3, 72-75. https://doi.org/ 10.3390/earth3010005

Academic Editor: Charles Jones

Received: 17 November 2021

Accepted: 4 January 2022

Published: 10 January 2022

Publisher's Note: MDPI stays neutral with regard to jurisdictional claims in published maps and institutional affiliations.

Copyright: (C) 2022 by the author. Licensee MDPI, Basel, Switzerland. This article is an open access article distributed under the terms and conditions of the Creative Commons Attribution (CC BY) license (https:// creativecommons.org/licenses/by/ $4.0 /)$.
Independent Researcher, 73100 Lecce, Italy; giuseppe.maggiotto@unisalento.it

\begin{abstract}
The Mediterranean region is a hot spot for climate change, and cities of this area will be exposed to both increasing temperatures and decreasing precipitations. Green Infrastructures (GIs) can lower urban temperatures through evapotranspiration with an adequate soil moisture content. Grey water reuse can both guarantee the right soil moisture content and reduce freshwater exploitation. In order to test the effectiveness of soil moisture on reducing air temperature, two modelling simulations ran with the microclimate CFD-based model ENVI-met 4.0. The chosen day was a registered heat wave (7 July 2019) in Lecce, a city of south Italy, which was selected as case study for the Mediterranean area. The results demonstrated the effectiveness of soil moisture on evapotranspiration in reducing air temperature. From a circular economy perspective, the supply of grey water for urban GIs represents a strategic adaptation strategy to the expected effects of climate change on the Mediterranean basin.
\end{abstract}

Keywords: grey water; Green Infrastructures; Mediterranean basin cities; Urban Climate; heat wave; climate change; Urban Heat Island; Park Cooling Island; adaptation strategies

\section{Introduction}

The Mediterranean region is a hot spot in terms of climate change [1], with projections that show the temperature will rise and precipitation will decrease [2]. Cities in this area will be thus exposed to both thermal issues and water scarcity. These consequences are exacerbated during summer heat waves that are expected to increase in frequency, intensity and duration [3]. It has been shown that Green Infrastructures (GIs, such as urban parks and gardens, green roofs and walls, street trees and hedges) can lower urban temperatures [4-6]. Parks have been demonstrated to play a significant role in reducing the Urban Heat Island (UHI) effect and lowering air temperature [7-9] with a cooling effect, referred to as the Park Cooling Island (PCI) effect $[10,11]$, that influences the microclimate of the area around a park. Urban vegetation is a mitigation tool for hot temperatures that works through direct shading on surfaces around plants and evapotranspiration that acts on latent heat fluxes, significantly reducing the quantity of heat that would be re-emitted by surfaces [12].

Evapotranspiration is a biophysical process whose effectiveness strongly depends on water availability: if natural soils are not irrigated during a hot day, they act as asphalt in terms of the microclimate [13] and thus worsen the increasing air temperature. It is essential to guarantee an adequate soil moisture content for parks through irrigation; nevertheless, climate change projections [2] in the Mediterranean area call for an alternative to reduce freshwater consumption [14]. Furthermore, most of the world's population lives in cities [15] and their exponential growth makes water shortage a challengeable threat $[16,17]$. Reusing domestically treated grey water (water used for laundering clothes, washing dishes or bathing) could help to guarantee soil irrigation without exploiting freshwater resources [18,19]. This could be an achievable solution since water quality for non-potable uses such as landscape irrigation can be realized more easily by using conventional and cost-effective treatment techniques such as coagulation, filtration and biological treatment systems [17]. The aim of this paper is to demonstrate the effectiveness 
of soil moisture content in reducing air temperature through evapotranspiration of a GI such as an urban park. The adequate soil moisture content for an urban park in the Mediterranean area should be guaranteed by freshwater plus grey water reuse in order to reduce pressure on freshwater sources because of the predicted water scarcity for the Mediterranean basin due to climate change.

\section{Materials and Methods}

For the purpose of this work, two simulations ran with the microclimate CFD-based model ENVI-met 4.0 [20]. The test was carried out for one day during a registered heat wave (7 July 2019) [21] in Lecce (UTM coordinates: $40^{\circ} 21^{\prime} \mathrm{N}, 18^{\circ} 10^{\prime} \mathrm{E}$ ), a city in south Italy, which was chosen as a case study for the Mediterranean area, previously validated with ENVI-met $[4,22]$. The study site was a hypothetical rectangular grass coverage urban park surrounded by buildings arranged to reproduce an outskirt configuration. A peripheral area was chosen because it potentially included wide spaces that offer the possibility to realize large urban parks and guarantee high volumes of grey water from buildings all around. ENVI-met simulations were made using a computational domain size of $200 \mathrm{~m} \times 200 \mathrm{~m}$, which was meshed by $50 \times 50$ square cells of $4 \mathrm{~m} \times 4 \mathrm{~m}$. Within the domain, the nested study site occupied an area of $160 \mathrm{~m} \times 160 \mathrm{~m}$ meshed by $40 \times 40$ square cells of $4 \mathrm{~m} \times 4 \mathrm{~m}$. The surface of the area was made of asphalt, except for the loamy soil under the grass coverage of the park. Simulations were named Case A and Case B. The modelling settings for Case A and Case B are the same for both simulations except for the soil moisture content of the park. On the basis of [23], simulation settings for Case A were configured with the reference value of critical crop humidity $(21 \%)$, while for Case B they were configured with the value of field capacity (66\%) for loamy soil, whereas critical crop humidity corresponded to the minimum humidity value that a plant needs to survive, and field capacity was the condition in which the soil holds all the water that is able to retain within its texture.

Figure 1 is the graph of air temperature measured by [21] for the date 7 July 2019 and calculated by the model at $2 \mathrm{~m}$ height in correspondence with the centre of the park. Case $\mathrm{B}$ values were lower than Case A from sunrise to night-time (23.00). Major differences were present during the hottest hours, and the maximum was at 13.00 with $1.6^{\circ} \mathrm{C}$.

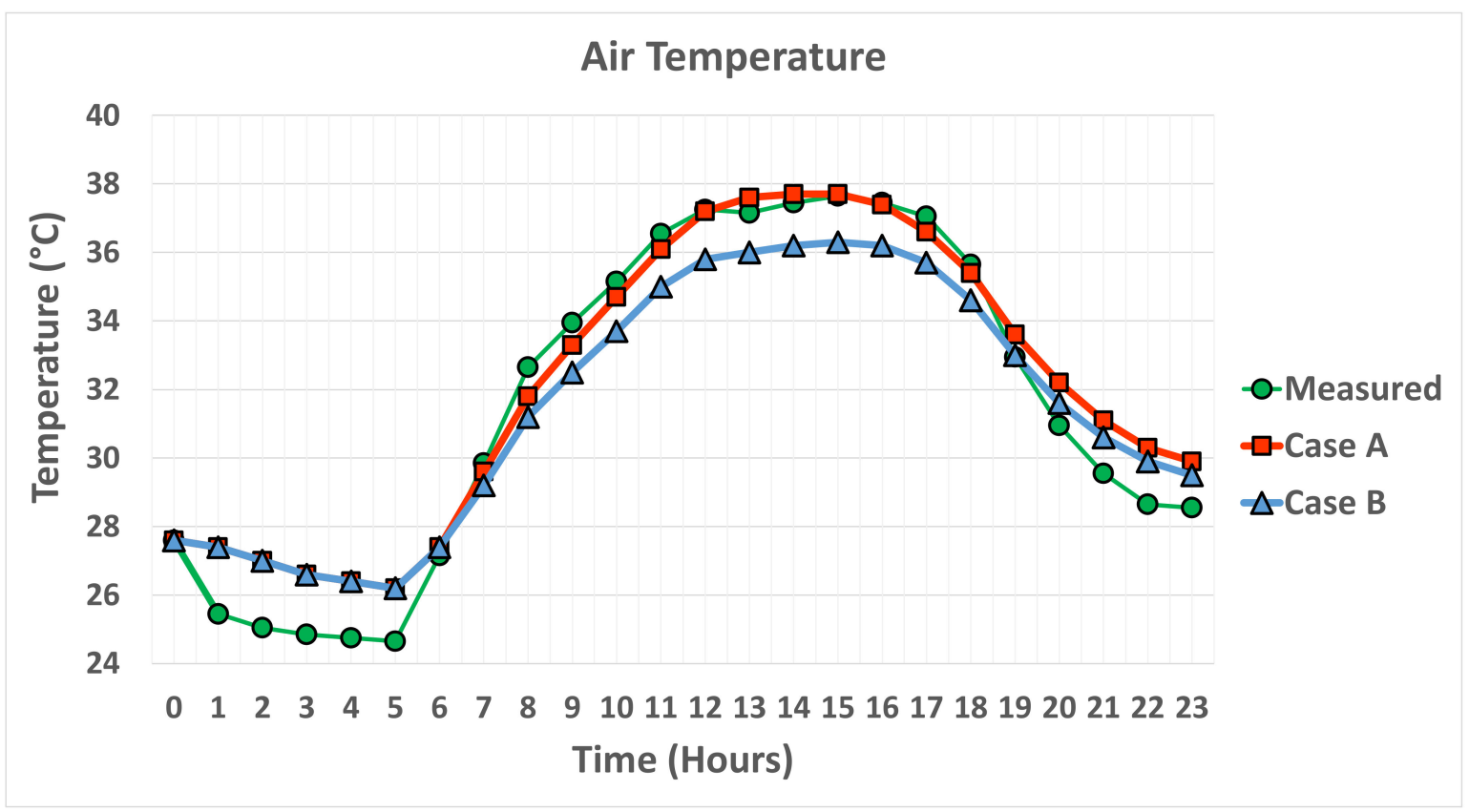

Figure 1. Measured (green graph with circular indicator) and calculated air temperature by the model for Case A (red graph with square indicator) and B (blue graph with triangular indicator) at $2 \mathrm{~m}$ height in correspondence with the centre of the park. 
This is an important aspect considering that even small changes (lower than $1^{\circ} \mathrm{C}$ ) can reduce health risks and save energy by reducing consumption. Figure 2 shows the temperature distribution of the study area at $2 \mathrm{~m}$ height at 13.00. Case A showed a cooler area in correspondence with the park, and the configuration of buildings generated hotter zones according to the modelled wind direction (S/W). Case B confirmed the pattern of temperature distribution of Case $\mathrm{A}$ and showed a diffused cooling for the whole area.

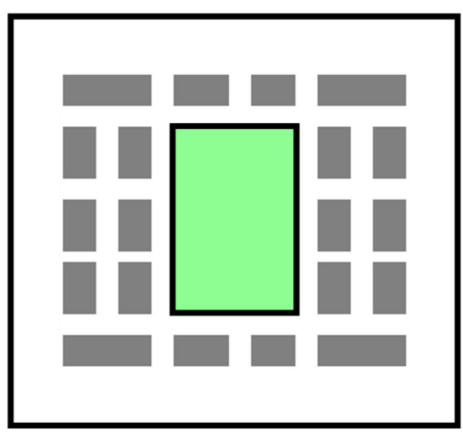

AREA INPUT FILE

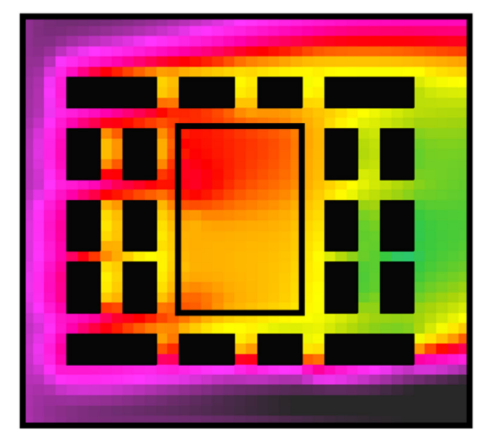

CASE A
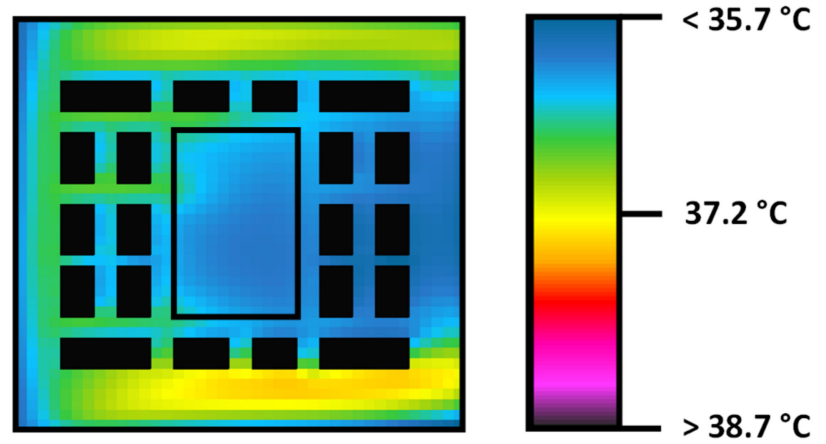

CASE B

Figure 2. Starting from the left: the ENVI-met area input file followed by the temperature distribution calculated by the model at $2 \mathrm{~m}$ height at 13.00 for Case A (soil moisture equal to $21 \%$ ) and for Case B (soil moisture equal to $66 \%$ ).

\section{Discussion}

These simulations represent a sensitivity test for soil moisture content, but further investigations should be made in order to check the influence of more structured GIs, including trees and hedges. The simulation ran under the condition of a heat wave, but several simulations should be compared under different meteorological scenarios and with different kinds of soil, vegetation, building configurations and meteorological conditions. Furthermore, an engineering study should calculate the volume of grey water produced by buildings around the park and consider the presence of a short storage system for a few days. Finally, the inclusion of relevant externalities might have a strong impact [24] on the economic aspect of the wastewater reuse project; thus, an economic feasibility study is always needed.

\section{Conclusions}

Climate change exposes the Mediterranean area to freshwater scarcity and increasing temperatures. GIs such as urban parks are recognized to mitigate high temperatures. Water availability should be guaranteed for urban parks because soil moisture content represents an important factor for vegetation effectiveness in reducing air temperature. From a circular economy perspective, the supply of grey water for urban GIs represents a strategic adaptation strategy to climate change for the Mediterranean basin that allows both urban temperature to decrease in in hot climate cities and the exploitation of freshwater resources to be reduced.

Funding: This research received no external funding.

Conflicts of Interest: The author declares no conflict of interest.

\section{References}

1. Giorgi, F. Climate change hot-spots. Geoph. Res. Let. 2006, 33, L08707. [CrossRef]

2. Lionello, P.; Scarascia, L. The relation between climate change in the Mediterranean region and global warming. Reg. Environ. Chang. 2018, 18, 1481-1493. [CrossRef]

3. Müller, N.; Kuttler, W.; Barlag, A.B. Counteracting urban climate change: Adaptation measures and their effect on thermal comfort. Theor. Appl. Climatol. 2014, 115, 243-257. [CrossRef] 
4. Maggiotto, G.; Miani, A.; Rizzo, E.; Castellone, M.D.; Piscitelli, P. Heatwaves and adaptation strategies in a mediterranean urban context. Environ. Res. 2021, 197, 111066. [CrossRef] [PubMed]

5. Shashua-Bar, L.; Hoffman, M.E. Vegetation as climatic component in the design of an urban street-An empirical model for predicting the cooling effect of urban green areas with trees. Energy Build. 2000, 31, 221-235. [CrossRef]

6. Zhao, W.; Wen, F.; Zhang, L.; Gao, Y.; He, J. Quantifying the Cooling Effects of the Green Vegetation in Xiamen City and Its Dynamics. Res. J. Environ. Sci. 2019, 32, 85-94.

7. Wong, N.H.; Yu, C. Study of green areas and urban heat island in a tropical city. Hab. Int. 2005, 29, 547-558. [CrossRef]

8. Sugawara, H.; Shimizu, S.; Takahashi, H.; Hagiwara, S.; Narita, K.; Mikami, T.; Hirano, T. Thermal Influence of a Large Green Space on a Hot Urban Environment. J. Environ. Qual. 2016, 45, 125-133. [CrossRef] [PubMed]

9. Yang, C.; He, X.; Yu, L.; Yang, J.; Yan, F.; Bu, K.; Chang, L.; Zhang, S. The Cooling Effect of Urban Parks and Its Monthly Variations in a Snow Climate City. Remote Sens. 2017, 9, 1066. [CrossRef]

10. Vidrih, B.; Medved, S. Multiparametric model of urban park cooling island. Urban For. Urban Green 2013, 12, 220-229. [CrossRef]

11. Nejatian, A.; Makian, M.; Gheibi, M.M.; Fathollahi-Fard, A. A novel viewpoint to the green city concept based on vegetation area changes and contributions to healthy days: A case study of Mashhad, Iran. Environ. Sci. Pollut. Res. 2022, 29, 702-710. [CrossRef] [PubMed]

12. Scudo, G.; Ochoa De La Torre, J.M. Spazi Verdi Urbani; Sistemi Editoriali: Rome, Italy, 2003.

13. Huttner, S.; Bruse, M.; Dostal, P.; Katzschner, A. Strategies for Mitigating Thermal Heat Stress in Central European Cities: The Project Klimes. In Proceedings of the Seventh International Conference on Urban Climate, Yokohama, Japan, 29 June-3 July 2009.

14. Thakur, J.K.; Karmacharya, S.; Singh, P.; Gurung, D.; Eslamian, S. Water Reuse Products in Urban Areas. In Urban Water Reuse Handbook; Eslamian, S., Taylor, F., Eds.; CRC Group: Boca Raton, FL, USA, 2015; Chapter 81; pp. 1055-1070.

15. United Nations; Department of Economic and Social Affairs, Population Division. World Urbanization Prospects-The 2011 Revision; CD-ROM, Ed.; United Nations: New York, NY, USA, 2012.

16. Fathollahi-Fard, A.M.; Ahmadi, A.; Mirzapour Al-e-Hashemac, S.M.J. Sustainable closed-loop supply chain network for an integrated water supply and wastewater collection system under uncertainty. J. Environ. Man. 2020, 275, 111277. [CrossRef] [PubMed]

17. Ajit, K. A Review on Grey Water Treatment and Reuse. IRJET 2016, 3, 2665-2668.

18. Ahmed, M.; Prathapar, S.; Al-Jamrah, A.; Al-Maskiri, A.; Al-Belushi, A. Greywater Reuse in Arid Countries: Problems and Possibilities. 2005. Available online: https://www.academia.edu/7512277/GREYWATER_REUSE_IN_ARID_COUNTRIES_ PROBLEMS_AND_POSSIBILITIES (accessed on 30 December 2021).

19. Akbarpour, N.; Salehi-Amiri, A.; Hajiaghaei-Keshteli, M.; Oliva, D. An innovative waste management system in a smart city under stochastic optimization using vehicle routing problem. Soft Comput. 2021, 25, 6707-6727. [CrossRef]

20. Envi-met. Available online: https:/ / www.envi-met.com/ (accessed on 30 December 2021).

21. Apulian Regional Agency for Prevention and Environment Protection (ARPA Puglia). Meteorological Service. Available online: http:/ / www.webgis.arpa.puglia.it/meteo/index.php (accessed on 30 December 2021).

22. Maggiotto, G.; Buccolieri, R.; Santo, M.A.; Leo, L.S.; Di Sabatino, S. Validation of temperature-perturbation and CFD-based modelling for the prediction of the thermal urban environment: The Lecce (IT) case study. Environ. Mod. Soft. 2014, 60, 69-83. [CrossRef]

23. Fugazza, M.; Il Terreno Caratteristiche e Proprietà. Course of "Sistemazione dei Bacini Idrografici". Available online: http: //www-3.unipv.it/webidra/materialeDidattico/fugazza/sistBacini/Suolo.pdf (accessed on 30 December 2021).

24. Garcia, X.; Pargament, D. Reusing wastewater to cope with water scarcity: Economic, social and environmental considerations for decision-making. Res. Conserv. Rec. 2015, 101, 154-166. [CrossRef] 